\title{
Thank you from HMPG and the editors
}

\section{The SAMJ reviewers}

HMPG and the editors of $S A M J$ would like to thank all who participated in the peer review process during this past year. We are grateful for the expertise, insight and thoughtful critiques shared with our authors through the review process, and without which maintaining the high standard of our journal would be impossible.

We apologise if any individual reviewer has inadvertently been excluded, and to those reviewers who were recruited after this issue was published.

Fareed Abdullah, South African Medical Research Council

Sumaiya Adam, University of Pretoria

Yasmin Adams, Chris Hani Baragwanath Academic Hospital/ University of the Witwatersrand

Miriam Adhikari, University of KwaZulu-Natal

Riedwaan Ally, University of the Witwatersrand

Elize Archer, Stellenbosch University

Márcio Araújo, International Integration of the Lusophone AfroBrazillian (Unilab)

Andrew Argent, University of Cape Town/Red Cross War Memorial Children's Hospital

Affirul Ariffin, Universiti Sains Islam Malaysia

Akwi Asombang, Beth Israel Deaconess Medical Center, Harvard Medical School

Marina Aucamp, Private

Daynia Ballot, University of the Witwatersrand

Peter Barron, University of the Witwatersrand

Wanda Bekker, University of KwaZulu-Natal

Michael Berry, Imperial School of Anaesthesia

Arvin Bhana, South African Medical Research Council

Rajendra Bhimma, University of KwaZulu-Natal

Jack Biko, University of Pretoria

Evan Blecher, University of Illinois at Chicago

Marc Blockman, University of Cape Town

Lucille Blumberg, National Institute for Communicable Diseases

Martin Both, Stellenbosch University

Adrian Brink, Ampath National Laboratory Services

Hanneke Brits, University of the Free State

Russell Britz, University of the Witwatersrand

Stevan Bruijns, University of Cape Town

Piotr Brezinski, Military Support Unit

Eckhart Buchmann, University of the Witwatersrand

Alex Butchart, World Health Organization

Neil Cameron, Stellenbosch University

Alain Chichom-Mefire, University of Buea

Chitalu Chama-Chiliba, University of Zambia

Lawrence Chauke, University of the Witwatersrand

Kathryn Chu, Médecins Sans Frontières

Damian Clarke, University of KwaZulu-Natal

Peter Cleaton-Jones, University of the Witwatersrand

Philip Cloete, University of Cape Town

Marius Coetzee, National Health Laboratory Service/University of the Free State

Diane Cooper, University of the Western Cape

Mark Cotton, Stellenbosch University

Herbert Cubasch, Chris Hani Baragwanath Academic Hospital/ University of the Witwatersrand

Christina Cutter, University of Michigan

Aqiel Dalvie, University of Cape Town

Alan Davidson, University of Cape Town

Victor Davies, University of the Witwatersrand
Halima Dawood, Grey’s Hospital

Renee de Waal, University of Cape Town

Wilma deWitt, University of Pretoria

Wim Delva, Stellenbosch University

Daan den Hollander, University of KwaZulu-Natal

Greta Dryer, University of Pretoria

Karen du Preez, Stellenbosch University

Jacques du Toit, Stellenbosch University

David Durrheim, University of Newcastle

Robin Dyers, Western Cape Government

Ian Edelstein, Human Sciences Research Council

Jennifer Edge, Private

Brian Eley, Red Cross War Memorial Children's Hospital

Denise Evans, University of the Witwatersrand

June Fabian, University of the Witwatersrand

Lee Fairlie, University of the Witwatersrand

Shinga Feresu, University of Pretoria

Nando Ferreira, University of Pretoria

Pierre Foex, University of Oxford

Sasha Frade, University of the Witwatersrand

Jennifer Geel, University of the Witwatersrand Stefan Gerbhart, Stellenbosch University

Brian Goemans, EMERGO, Underwriters Laboratories

David Greenfield, University of Cape Town

Andrew Grieve, University of the Witwatersrand

Larry Hadley, University of KwaZulu-Natal

Timothy Hardcastle, University of KwaZulu-Natal

Haly Holmes, University of the Western Cape

Muhammad Hoque, University of Limpopo (Medunsa Campus)

Johan Hugo, Anova Health Institute

Francis Hyera, University of Limpopo

Eduard Jonas, University of Cape Town

John Joska, University of Cape Town

Ben Jugmohan, University of the Witwatersrand

Sharon Kling, Stellenbosch University

Karen Koch, University of the Witwatersrand/Donald Gordon Hospital Jake Krige, University of Cape Town

Carl-Heinz Kruse, Grey’s Hospital

Suresh Kumar, Jawaharlal Institute of Postgraduate Medical Education and Research

Yves Lafort, Ghent University

Sanjay Lala, University of the Witwatersrand

James Leckman, Yale School of Medicine

Richard Lessells, London School of Hygiene and Tropical Medicine

Cecil Levy, Charlotte Maxeke Academic Hospital

Jeffrey Lipman, University of the Witwatersrand

Jerome Loveland, University of the Witwatersrand

Irene Lubbe, University of Pretoria

Christina Lundgren, University of the Witwatersrand

Johnny Mahlangu, University of the Witwatersrand

Hassan Mahomed, Stellenbosch University/Western Cape Government: Health

Ozayr Mahomed, University of KwaZulu-Natal

Johan Marais, African Snakebite Institute

Cathy Mathews, South Africa Medical Research Council

Richard Matzopoulos, South African Medical Research Council/

University of Cape Town/University of the Witwatersrand

David McQuoid-Mason, University of KwaZulu-Natal

Graeme Meintjies, University of Cape Town

Mervyn Mer, University of the Witwatersrand

Fraukje Mevissen, Maastricht University 
Johanna Meyer, Sefako Makgatho Health Sciences University

Peter Millard, University of New England

Malcolm Miller, Groote Schuur Hospital

Jacqui Miot, University of the Witwatersrand

Zainab Mohamed, Groote Schuur Hospital

Elizabeth Molyneux, University of Malawi

Daya Moodley, University of KwaZulu-Natal

Anisa Mosam, University of KwaZulu-Natal

Susan Msadabwe, Cancer Diseases Hospital, Ministry of Health

David Muckart, University of KwaZulu-Natal

Elmi Muller, University of Cape Town

Landon Myer, University of Cape Town

Saloshini Naidoo, University of KwaZulu-Natal

Pradeep Navsaria, University of Cape Town/Groote Schuur Hospital

Jabulani Ncayiyana, University of the Witwatersrand

Charles Ngwena, University of Pretoria

Nicolas Novitsky, University of Cape Town

Duduzile Nsibande, Medical Research Council

Ntobeko Ntusi, University of Cape Town

Julian Oettle, University of the Witwatersrand

Okechukwu Ogah, University College Hospital, Ibadan

Emmy Okello, Uganda Heart Institute/Makerere University

Steve Olorunju, Medical Research Council

Andy Parrish, Walter Sisulu University/Cecilia Makiwane Hospital

Mososa Patel, University of the Witwatersrand

Robert Pattinson, University of Pretoria

Olga Perovic, National Institute for Communicable Diseases

Velisha Perumal, University of KwaZulu-Natal

Kubendran Pillay, Private

Fraser Pirie, University of KwaZulu-Natal

Frances Priddy, International AIDS Vaccine Initiative

Helena Rabie, Stellenbosch University

Arthur Rantloane, University of Pretoria

Bernardo Rapoport, Medical Oncology Centre of Rosebank

Mpho Ratshikana-Moloko, University of the Witwatersrand

Sarah Rayne, University of the Witwatersrand

Brian Rayner, University of Cape Town

Kate Rees, Anova Health Institute

Jürgen Rehm, Centre for Addiction and Mental Health (CAMH)

Gina Rencken, University of KwaZulu-Natal

Helmuth Reuter, Stellenbosch University

Anne Robertson, University of Limpopo

Reitze Rodseth, University of KwaZulu-Natal.

Susanne Roley, Collaborative for Leadership in Ayres Sensory

Integration

Charl Roux, University of Johannesburg

Paul Ruff, University of the Witwatersrand

Haroon Saloojee, University of the Witwatersrand

Yusuf Saloojee, National Council Against Smoking

Helen Schneider, University of the Western Cape

Kathryn Schnippel, University of Cape Town

Motshedisi Sebitloane, University of KwaZulu-Natal

Mohammed Seedat, University of South Africa

Sherona Seetharam, University of the Witwatersrand/Lancet Laboratories

Hannah Simonds, Tygerberg Academic Hospital

Elvira Singh, National Health Laboratory Service

Kevin Spicer, Kentucky Department for Public Health

Egilius Spierings, MedVadis Research

Vanessa Steenkamp, University of Pretoria

Victoria Stephen, Thelle Mogoerane Regional Hospital

Ramudungoane Tabana, University of South Africa

Allan Taylor, University of Cape Town

Gerhard Theron, Stellenbosch University
Ciprian Tomuleasa, Oncology Institute 'Prof. Dr. Ion Chiricuţă’

Joyce Tsoka-Gwegweni, University of KwaZulu-Natal

Richard van-Zyl Smit, University of Cape Town

Arnaud Vincent, Erasmus University Medical Center

Linda Visser, University of KwaZulu-Natal

Mari Viviers, Sefako Makgatho Health Sciences University

Tim Walker, University of Rwanda/Butare University Teaching Hospital

Cathy Ward, University of Cape Town

Nicola Wearne, University of Cape Town

Andrew Whitelaw, Stellenbosch University

Janine Wichman, University of Pretoria

Margaret Williams, Nelson Mandela Metropolitan University

Charles Wiysonge, Stellenbosch University

Darryl Wood, Queen's Hospital Emergency Department/Queen

Mary University

Caradee Wright, South African Medical Research Council

Michelle Youngleson, Institute for Healthcare, Boston/University of Cape Town

Virginia Zweigenthal, University of Cape Town

\section{The CME guest editors and authors}

As editor of CME and $S A M J$, I would like to thank all the guest editors and authors for their truly outstanding contributions to CME during 2017. This is much appreciated, particularly in the face of increasingly heavy clinical and teaching loads.

\section{Anaemia (parts 1 and 2)}

Guest editor: N Alli

Authors: N Alli, J Vaughan, M Patel

Prevention of childhood injuries (parts 1 and 2)

Guest editors: A B van As, A van Niekerk

Authors: M Arnold, A B van As, A Numanoglu, A van Niekerk, R Govender, R Jacobs, D K Kimemia, Y Ferreira

\section{Tuberous sclerosis complex}

Guest editor: P J de Vries

Authors: P J de Vries, L Leclezio, J M Wilmshurst, G Fieggen, E Gottlich, L Jacklin, I P Naiker, R Newaj, D Shamley, B Schlegel, A Venter

Wilderness medicine (parts 1 and 2)

Guest editors: R Hofmeyr, J Matthew, R De Decker, S Buchanan, G Tölken

Authors: R Hofmeyr, G Tölken, R De Decker, J Matthew, C Robertson, $S$ Buchanan, C D’Alton, J Roos

Chronic kidney disease

Guest editor: A M Meyers

Authors: A M Meyers, M Davies

Contraceptive implants (parts 1 and 2)

Guest editors: S Mullick, M F Chersich, Y Pillay, H Rees

Authors: D Pillay, M F Chersich, C Morroni, M Pleaner, O A Adeagbo, N Naidoo, S Mullick, H Rees, J Smit, N Lince-Deroche, M Makua, Y Pillay

Bridget Farham
Editor
ugqirha@iafrica.com

S Afr Med J 2017;107(12):1045-1046. DOI:10.7196/SAMJ.2017.v107i12.12985 